12th LUMEN International Scientific Conference Rethinking Social Action. Core Values in Practice | RSACVP 2019 | 15-17 May 2019 | Iasi-Romania

\title{
Economical Analysis of the Economical- Mathematical Model Construction Concerning the Contributing Factors of the Current Migration Processes Evidenced by the Example of the Interrelations between Georgia and the EU Countries
}

\author{
Davit BIDZINASHVILI \& Karlo TSERTSVADZE
}

https://doi.org/10.18662/lumproc.149

How to cite: Bidzinashvili, D., \& Tsertsvadze, K. (2019). Economical Analysis of the Economical-Mathematical Model Construction Concerning the Contributing Factors of the Current Migration Processes Evidenced by the Example of the Interrelations between Georgia and the EU Countries. In C. Ignatescu (ed.), 12th LUMEN International Scientific Conference Rethinking Social Action. Core Values in Practice, 15-17 May 2019, Iasi - Romania (pp. 13-25). Iasi, Romania: LUMEN Proceedings. https://doi.org/10.18662/lumproc.149 



\title{
Economical Analysis of the Economical- Mathematical Model Construction Concerning the Contributing Factors of the Current Migration Processes Evidenced by the Example of the Interrelations between Georgia and the EU Countries
}

\author{
Davit BIDZINASHVILI ${ }^{1}$, Karlo TSERTSVADZE ${ }^{2}$
}

\begin{abstract}
The issue of migration is a critical issue and a problem for the whole world. The main reasons for universal migration can be considered as follow: economic, professional, political, relief, ethnic and others. The work equally deals with both internal and external migrations. International migration is much bigger problem, as it has become very rapid and aggravated. The flow of migrants in Europe became a great problem for European leaders. Our goal is to build a mathematical model based on existing data, which will cover all the major reasons that affect the migration process; Analysis of how to effect a change in the migration process will help to enbance and improve the legal migration capabilities.
\end{abstract}

Keywords: Migration; migration factors; migration process; mathematical model; employment; demographic policy.

\section{Introduction}

Migration is the topical theme and problem for the countries all over the world. There are several factors of migration. The most important factors causing the migration processes can be the following: economical, professional, political, religious, and ethnical. These factors equally concern

\footnotetext{
1 Prof. Dr., Gori State Teaching University, faculty of Social Sciences, Business and Law, Georgia; E-mail: davitbidz@gmail.com

2 Prof. Dr., Gori State Teaching University, faculty of Social Sciences, Business and Law, Georgia; E-mail: karlotsertsvadze@mail.ru 
internal and outer migrations. The international migration processes nowadays represent the most serious and critical problem. The great flow of migrants on the European territory became the great trouble for the European leaders.

Nowadays Europe is in the difficult situation: on the one hand there is the idea of humanism as one of the main European values and on the other hand - the security problem. The crisis now has already reached its peak and it should be solved as soon as possible which demands rapid response from the European countries to the intensive flows of migrants. Our aim is to construct such mathematical model based on the current data which will consider all the main causes influencing the migration processes; the analysis will be done in relation to the question - how the changes in the separate influencing factors of the migration processes will influence the whole process of migration. This will be a great help in the processes of widening and improving the abilities of the legal migration processes.

\section{Problem Statement}

Labor migration of the people aiming to be employed is a serious global problem which nowadays concerns the majority of the countries in the world. It is conditioned by two factors acting on the world labor market: the majority of the working-age population either cannot find any job in their own country or cannot find the proper job ensuring proper life for their families. At the same time, in many countries there is a shortage of manpower. There are also the other factors such as: changes in demography, social-economical and political crises, increasing difference between the levels of labor compensation in the developing and developed countries. All those reasons result in the increasing number of the people crossing the borders in their search for a job. Besides this, the number of the women migrating independently, seeking for a job, increased seriously. Their number amounts to the half of the whole number of the job migrants. The problems related to the border crossings can not be effectively solved unless the countries act in coordination and not separately. It can be concluded that the collaboration between the countries in the sphere of migration processes will ensure safety for the national interests [6].

At present, approximately $105 \mathrm{mln}$ people are working out of the borders of their countries. Labour mobility became one of the main characterisitics of globalization and global economics. The income of the labour migrants reached 450 billion dollars in 2016. According the data of 
the World Bank more than 350 billion dollars were transferred as immigrant remittances to the developing countries [2].

In 2009, within the European Neighborhood and Partnership Policy, the ambitious initiative of the Eastern partnership on the basis of the declaration, gave a new impulse to the EU foreign and security policy as well as to the future efforts of six countries of the former USSR - close approach to the EU [3].

In the context of the mutual relationships, collaboration between The EU and Georgia in the sphere of labor migration regulations is of great importance. The neighborhood policy of Europe and the Eastern partnership initiative gave a great impulse to the development of the migration control system in the country.

As it was mentioned above, the "partnership for mobility" initiation aims taking collective measures against illegal migration and promoting legal migration. Thus it implies collaboration over solving the problems related to migration processes such as: labor migration, readmission, reintegration, diasporas, documents security, labor market, and recognizing the professional qualification [1]. Within this initiative, the agreements were signed between the EU and Georgia "On Simplification of the Visa Procedures" and "On Readmission for the Persons Living Illegally". Both of the mentioned agreements represent the instruments against the illegal migration [7].

The goal of the Georgian migration policy is to create the legal institutional space in the country for migration control to the year 2020. This system will benefit to the closer relations between Georgia and the EU; to peaceful cohabitation of the groups of people of the different ethnos, cultures and religions; will defend the rights of the immigrants and their successful integration in the other society; will support the rights of the returned immigrants and their reintegration in the own society, using the demographically and economically positive aspects of the migration in the development of the country, will increase the possibilities of the illegal migrations for the citizens of Georgia [5].

Resulting from this situation, Georgia faces three main challenges: 1. Decreasing the number of the illegal migrants first through improving the knowledge of the potential or actual migrants about this issue and also through widening the possibilities of the legal migration of the citizens of Georgia in other countries which will result in decreasing the number of illegals from Georgia. 2. Proactively defend the rights of immigrants living abroad legally or ilegally, help them to retain their national identity, especially in the countries where the number of migrants from Georgia is high. 3. Improve the existing tools for better registering and studying all kinds of migration flows [5]. 
The character of migration flows from Georgia, their directions and amplitudes have basically changed during the last decades. Nowadays there are Georgian emigrants in the countries all over the world. These flows spread in direction of many different countries.

Emigrants from Georgia are basically labor migrants; their aim is to get well paid jobs and to support their families in Georgia financially to resolve different kinds of problems. Their families are dependent on the money transfers as they can cover their daily expenses. As for the money to start some business or make investments or make some savings, such cases are very rare.

Labor migration out of the borders threatens the demographic situation in Georgia. Usually, the most part of the labor migrants are people in their working capacity and of the fertile age. They might delay starting their family lives or might get married abroad, lead a family life there, have children and thus postpone their returning to home. As a result, the serious human resources might not be used fully in the home country. The priorities named below are designed to diminish the mentioned risks.

Resulting from the fact that the main factors of the internal and outer migration have basically economical character, it is very important to analyze them more widely, in the light of social-economical development of the country. Thus, we need to realize such policy which will enable using the potential of the migrants in favor of the social-economical development of the country and diminish the risks for the country's demographic security.

\section{Research Questions/Aims of the research}

Our aim is to construct such mathematical model based on the current data which will consider all the main causes influencing the migration processes; the analysis will be done in relation to the question how the changes in the separate influencing factors of the migration processes will influence the whole process of migration. This will be a great help in the processes of widening and improving the abilities of the legal migration processes.

\section{Research Methods}

The methods of scientific abstraction, analysis, synthesis, and statistical data gathering, accumulating and grouping have been used during the researches. 


\section{Discussions}

In 2015 the government of Georgia approved the "Migration Strategy for the years 2016-2020" which is oriented on the international migration process and involves the areas of priority, such as: to support the legal migration, deal with illegality, develop the asylum system, improve control over migration processes, raise public consciousness, widen collaboration between the countries, Thus, it can be concluded that control over the internal mobility within the society, especially in the cases of armed conflicts or of the social-economical and ecological reasons - these are the issues which demand more attention and research.

There are about 13-14 million immigrants in the EU countries (including the family members). About 8 million people out of this number (i.e. 61\%) are from the countries which are not the EU members. In Germany $8 \%$ out of the total number of the employed people are immigrants, in France this number shows $7 \%$, in Switzerland and Luxemburg $-30 \%$.

Resulting from the EU extension, the migration flow became more extensive from the East Europe to the West. The main hosting countries are Great Britain, Ireland and Sweden. This wave of migration is characterized with economical motivation and legality.

After the WWII there were hard times when great flows of the refugees which reached their maximum, rolled over the whole Europe. Nowadays the migration processes also result in large number of hard problems. The representatives of different specialties - economists, politicians and others were involved in the discussion on this issue. The flow which came to Europe from Africa and Middle East became a great problem for the European leaders. Today the European leaders are facing a great dilemma, a great challenge: from one side Europe is declares the ideals of humanism and on the other side - they must think about European security. The crisis has already reached its critical phase and demands rapid response from the European states.

Migration caused a lot of problems not only in receiving countries but in the giving countries as well. Kinds of influence of migration on the countries of departure:

1. Departing the part of the population in the active working age from the country (15-65 years old.)

2. Damaging the gender-age structure.

3. Increasing the number of the elderly age population and others.

Within the countries the tensions between the local population and migrants are usual. The causes are as follows: racism, ethnical contradictions. 
For example, Cyprus government has announced that the country can receive only Christian migrants but not Muslims. The same is about Slovakia; the migrants also have problems with the indigenous population expressed in cultural incompatibility and difficulties with the integration. Another most frequent problem is language barriers. Today the European countries found themselves in the complicated situations because of increasing number of the criminal cases and several kinds of the terrorism. The terroristic acts happened in France and created great dangers for other countries too. Because of this reason in November 2015 the summit was held in Valetta where the leaders of the European countries discussed these serious issues. During this summit it was decided that EU would send 1,800 000 Euros to Turkey and Africa so that these countries would not send large flows of the migrants to Europe and would ensure good living conditions for the migrants in their countries.

The European Union settled quotes system for migrants. Romania, Czech Republic, Hungary, Finland and Slovakia were against the quotes but by the majority of voices this system was accepted. At present the registrations are being conducted in the countries and in a very short time the exact data about number of the migrants will be registered in each country.

The following problems which the migrants encounter with can be named as: 1. Racial contradictions; 2. Cultural differences; 3. Religious opposition; 4.Language barriers. 5. Education; 6.Low job qualifications and different styles of life; also differences in traditions; 7.Concurrent labour force; 8.Xenophobia; 9. Racist behavior; 10. Possible number of vagabonds; 11.Possible number of criminals; 12. Number of homeless people; 13. Illnesses; 14. Nostalgia. Such problems have already appeared even in the USA. Immigration turned less problematic among the countries of the Arabian Gulf (easy cultural adaptation, absence of the language barriers and similar religious relationships).

Migration is a problem not only for receiving countries but for the giving countries as well 1.The age structure of the population is destroyed (the young people are migrating); 2. Birth rate decreased; 3. There is a deficiency of the manpower; 4. Deficiency of the qualified workers; 5 . Large sums of money spent by the country to each young person (as investment) turn out as lost; 6 . Personal problems - disintegrating of families, nostalgia.

There are positive and close relations between the EU and Georgia. The association agreement between them became effective in July 2016. It aims to have closer political ties and to support economical integration. Whereas, in 2014 EU and Georgia signed the agreement on the Deep and Comprehensive Free Trade area (DCFTA). [8] Beginning from March 28, 2017 the citizens of Georgia enjoy the possibility to travel to Europe visa 
free. European Union is the biggest trade partner of Georgia. It provides grant to Georgia as much as 350 million GELS (120 million Euros) every year. On March 9, 2016, the European Commission officially presented the legislative proposal N 539/2001 to the European Parliament and EU Council about the changes in the regulations. This proposal foresaw establishing the regime of short term visa free movement according to which the citizens of Georgia having the biometric passports could travel to Europe for short time. The European Union institutions were discussing this issue during a year and finally, on February 2, 2017 this proposal was accepted by Euro parliament and then, on February 27, it was approved by The EU Council. On March 1, the same year, the President of the Euro parliament and the representative of the Head of the European Council signed this document. Later, on March 8, it was published in the official journal of the EU.

Beginning from March 28, 2017 the citizens of Georgia travelled visa free to the European Union/Schengen zone countries.

Table 1. Number of Emigrants According their Gender And type of Residence [9]

\begin{tabular}{|c|c|c|c|c|c|}
\hline \multirow{2}{*}{\multicolumn{2}{|c|}{$\begin{array}{l}\text { Present country } \text { Both } \\
\text { of residence } \quad \text { gender }\end{array}$}} & \multicolumn{2}{|c|}{ Gender } & \multicolumn{2}{|c|}{ Type of the Settlement } \\
\hline & & male & female & town & village \\
\hline Greece & 14,048 & 2,386 & 11,662 & 8,762 & 5,286 \\
\hline Italy & 9,612 & 1,373 & 8,239 & 6,756 & 2,856 \\
\hline Germany & 6,259 & 2,808 & 3,451 & 4,831 & 1,428 \\
\hline USA & 5,021 & 2,457 & 2,564 & 4,474 & 547 \\
\hline Spain & 3,597 & 1,724 & 1,873 & 2,618 & 979 \\
\hline France & 3,293 & 1,896 & 1,397 & 2,730 & 563 \\
\hline
\end{tabular}

Source: Geostat, official census of citizens of Georgia 2014 
Davit BIDZINASHVILI et al. | Lumen Proceedings 9 | RSACVP2019

Table 2. The Data of Emigrants from Georgia According the Countries of Permanent Residence [10]

\section{0-2015}

\begin{tabular}{|c|c|c|c|c|c|c|c|c|}
\hline Country & data type & Year 2000 & $\begin{array}{l}\text { Data } \\
\text { type }\end{array}$ & Year 2005 & type & $\begin{array}{l}\text { Year } \\
2010\end{array}$ & $\begin{array}{l}\text { data } \\
\text { type }\end{array}$ & Year 2015. \\
\hline Russia & B & 625,743 & B & 539,318 & B & 441,793 & B & 450,221 \\
\hline Greece & B & 71,047 & B & 78,132 & B & 85,216 & B & 83,388 \\
\hline Ukraine & B & 73,621 & B & 67,270 & B & 64,185 & B & 64,399 \\
\hline Azerbaijan & BR & 61,708 & BR & 58,561 & BR & 53,614 & BR & 51,141 \\
\hline Armenia & BR & 46,779 & BR & 30,942 & BR & 25,767 & BR & 40,897 \\
\hline USA & B & 10,528 & B & 15,424 & B & 20,511 & B & 24,456 \\
\hline Germany & B & 10,482 & B & 16,302 & B & 22,122 & B & 22,884 \\
\hline Cyprus & B & 6,950 & B & 10,173 & B & 16,310 & B & 17,026 \\
\hline Italy & B & 317 & B & 6,271 & B & 12,224 & B & 12,226 \\
\hline Israel & BR & 21,123 & BR & 14,988 & BR & 9,034 & BR & 9,317 \\
\hline Spain & B & 523 & B & 4,926 & B & 9,792 & B & 8,760 \\
\hline Belarus & B & 8,827 & B & 8,705 & B & 8,583 & B & 8,507 \\
\hline France & B & 1,424 & B & 5,304 & B & 7,011 & B & 7,584 \\
\hline Turkey & BR & 6,065 & BR & 6,249 & BR & 6,439 & BR & 6,536 \\
\hline EU & & 100813 & & 133494 & & 168542 & & 171030 \\
\hline $\begin{array}{l}\text { All } \\
\text { countries }\end{array}$ & & 967,810 & & 886,964 & & 810,207 & & 838,430 \\
\hline
\end{tabular}

Table 3. The number of the acting residence permits given to the citizens of Georgia in 28 European countries according theyears and the reasons. [11]

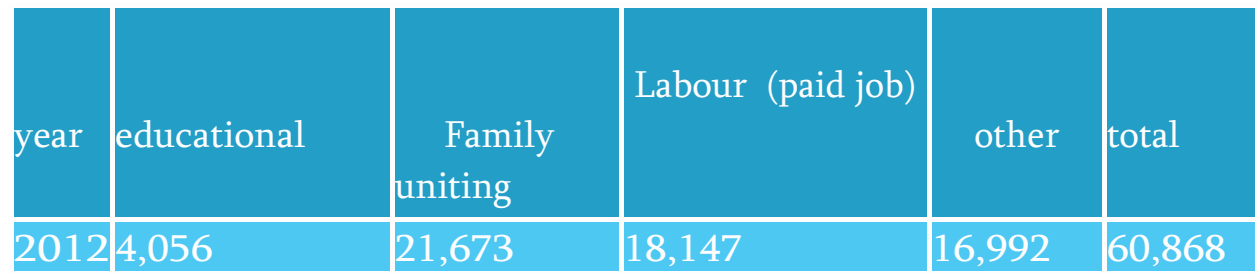




\begin{tabular}{|l|l|l|l|l|l|}
\hline 2013 & 4,150 & 24,419 & 19,301 & 18,413 & 66,283 \\
\hline 2014 & 4,360 & 25,086 & 19,563 & 20,863 & 69,872 \\
\hline 2015 & 4,626 & 25,547 & 18,411 & 22,639 & 71,223 \\
\hline 2016 & 4,730 & 26,538 & 18,435 & 24,713 & 74,416 \\
\hline
\end{tabular}

Migration can favor the economy of the country, e.g. this can be seen from the international money transfers. It is not rare that such transfers represent one of the main sources of the foreign currency flow and aids in stabilization of the country's local currency. [5] During the crisis periods of the country those transfers help in diversification of the existing risks and are of great help for the economy of the country. The money transfers come from the migrants living and working in the different countries as they are trying to support their families.

The full range of the migration problems which can be studied on the basis of the economical-mathematical models suggested in our work is very wide, beginning from the economical analysis, including the prognosis or executive decisions. Using the economical-mathematical tools is very important for rationally conducting the migration policy. This can give us especially useful information when we watch the process through its dynamics.

Migration processes are characterized by particular complexity and this once more confirms the necessity of using the economical-mathematical modeling. In order to make reality simpler, not so complicated, many restrictions as well as admissions should be used. As most part of the migration processes do not reveal themselves as clear and explicit ones and correspondingly, it is practically useless and undesirable to use linear approaches. In order to achieve successful results in using this modeling it is necessary to choose reliable methods for getting and processing the information. The theoretical approaches are also multiple which means that several different ways of mathematical modeling can be used. Due to dynamics and indefinity of the mathematical modeling to choose the characteristics of migration processes is a difficult job.

The above said aims also to develop such instrumental tools which can make it possible to make researches about the migration processes.

Our aim is to make such model on the basis of the existing data, which will foresee all the main causes influencing the migration processes; we will also use this approach in order to analyze how any change of causes can influence the migration process; 
Let us introduce the symbols:

i - a cause triggering migration;

$\mathrm{k}$ - number of the causes of migration;

$\mathrm{i}=1 ; 2 ; \ldots ; \mathrm{k}$.

T -the period of migration process under study (1990-2017);

$\Delta \mathrm{t}-\mathrm{a}$ sub-period, in which the studied periods are divided.

$\mathrm{n}$ - number of sub-periods $\frac{\mathrm{T}}{\Delta \mathrm{t}}=\mathrm{n}$

$\mathrm{t}$ - number of the sub periods $\mathrm{t}=1 ; 2 ; \ldots \mathrm{n}$

$\mathrm{X}_{\mathrm{i}}(\mathrm{t})$ - the number of the emigrants depending on the $\mathrm{i}$ cause in the t-sub period.

$\mathrm{X}_{\mathrm{i}}(\mathrm{T}) \varphi$ - number of emigrants caused by $\mathrm{i}$-cause in the observed T-period.

It can be easily understood that

$$
\mathrm{X}_{\mathrm{i}}(\mathrm{T})=\sum_{\mathrm{t}=1}^{\mathrm{n}} \mathrm{X}_{\mathrm{i}}(\mathrm{t})
$$

Where $\mathrm{x}(\mathrm{t})$ denotes total number of the emigrants in the $\mathrm{t}$ sub period of time. It is clear that

$$
\mathrm{X}_{\mathrm{i}}(\mathrm{t})=\sum_{\mathrm{t}=1}^{\mathrm{k}} \mathrm{X}_{\mathrm{i}}(\mathrm{t})
$$

$\mathrm{X}(\mathrm{T})$ denotes a total number of the emigrants in the observed $\mathrm{T}$ period under study, and it is easy to conclude that

$$
\mathrm{X}_{\mathrm{i}}(\mathrm{T})=\sum_{\mathrm{t}=1}^{\mathrm{n}} \mathrm{x}(\mathrm{t})
$$

As it was said above, during the different stages, the factors which cause migration have different kinds of influences on different sub periods. In order to characterize the influence of each cause on the sub period, we should introduce the notion of weight. We shall mark the weight of $\mathbf{i}$ cause for the $\mathbf{t}$ sub-period as $\mathrm{a}_{\mathbf{i}}(\mathrm{t})$.

$$
a_{i}(t)=\frac{x_{i}(t)}{x(t)}
$$

It can be seen that "weight" always hesitates between null and one $0 \leq \mathrm{a}_{\mathrm{i}}(\mathrm{t}) \leq 1$

And here we should denote that

$$
\sum_{\mathrm{t}=1}^{\mathrm{k}} \mathrm{a}_{\mathrm{i}}(\mathrm{t})=1
$$


Analogously we define the "weight" of the i-causes during the whole period under investigation:

$$
a_{i}(T)=\frac{x_{i}(T)}{x(T)}
$$

And here $0 \leq \mathrm{a}_{\mathrm{i}}(\mathrm{T}) \leq 1$

$$
\sum_{\mathrm{t}=1}^{\mathrm{k}} \mathrm{a}_{\mathrm{i}}(\mathrm{T})=1
$$

The sequence $a_{i}(t)(t=1 ; 2 ; \ldots n)$ shows how the $i$-cause influences changes during the $\mathrm{T}$ period under investigation. If $\mathrm{a}_{\mathrm{i}}(\mathrm{t})$ increases in any interval within $\mathrm{T}$ period, we can conclude, that the influence of $\mathrm{i}$-cause increases. Correspondingly, if the sequence $a_{i}(t)$ decreases towards $t$, we conclude that influence decreases.

Resulting from their nature, $\mathrm{X}_{\mathrm{i}}(\mathrm{t})$ and $\mathrm{x}(\mathrm{t})$ are the casual processes. According the character of our task this will be evaluation of the unknown parameter, in case if the task of prognosis on the basis of the existing data and admitting that this process is stationary, the task will be solvable [4].

\section{Conclusions}

Basing on the represented information we can conclude that the factors provoking the illegal migration differ in the different countries, according to the individual needs of their populations. In case of Georgia, illegal migration is conditioned by low economical development. When an average payment can sometimes be lower than an average living minimum, it is not surprising that people try to escape hunger and poverty and many of them try to leave their country becoming the illegal migrants As for the EU countries, they are considered as developed countries, having high economical potential, their cultural development is on the high level, migrating to such countries seems very attractive and people try to enter those countries bearing great hopes for the future. It is especially important to develop the policy in Georgia, which will encourage using all the human and financial resources and experiences accumulated during the migration period in order to create stable economical situation in the country. Especially important is to support them by giving a real estate in the countryside. Then the population will remain in the country and continue to work and develop here; this will slow down the tendencies of migration and 
urbanization. The measures should be taken to encourage the emigrants to come back to the native country and reintegrate here.

The Georgian Diaspora can play the important role in development of the regions of the country and to create employment possibilities. The entrepreneurs, representatives of the Diaspora can become interested in cooperation with other entrepreneurs in their native country and/or in doing mutual businesses and make mutual investments in such sectors as sending to their compatriots the agricultural or some other production from the native country, to benefit to the tourism sector in their regions.

We think that the following measures are necessary:

a. To support development of the small and medium businesses working due to the money transfers from the emigrants;

b. To enlarge and strengthen the cooperation between the Diasporas in other countries and the population living in Georgia. This will be especially useful for the economical development of the regions. Such cooperation will be encouraged to become more active. Effective public or private business partnership should be developed.

It is not and really cannot be easy for the migrants returned to their country to reintegrate here. It often happens that migrants return to the home, buy products and real estate paying their savings but some time later they return to their place of migration. Their argument is that socially almost nothing changed in Georgia and economically they prefer to live and work abroad where they can get more payment.

The qualification got by the Georgian migrants abroad and their skills can be very valuable for their country as an additional resource. It can be used to ensure demographic security, to participate in the processes working out the policy and strategies for development of the country they can also participate in improving the activities aiming to improve the abilities of the nongovernmental organizations and private sector.

The main priorities for the Georgian government should be: political association and economical integration with the EU, gradual closing of the legislation of the country with the legislation of the EU, and dynamic integration of the European systems of standards on the national level.

\section{References}

[1] Agreement between the European Union and Georgia on the readmission of persons residing without authorization; 
Davit BIDZINASHVILI et al. | Lumen Proceedings 9 | RSACVP2019

[2] http://www.iom.int/cms/en/sites/iom/home/what-we-do/labour-migration. Html https://ec.europa.eu/home-affairs/what-we-do/policies/borders-andvisas/visa-policy en 31.10.2017;

[3] Council of the European Union. Joint Declaration of the Prague Eastern Partnership Summit, 7 May, 2009;

[4] Tsertsvadze K, Tsertsvadze A. About the mathematical processing of the migration process (in Georgian). Gori State University, Scientific Papers \#3, 2006;

[5] Migration strategy of Georgia of the years 2016-2020;

[6] Multilateral Fundamentals in the Labour Migration, Issues by the International Labour Organization, 2010;

[7] Official Journal of the European Union. 25 February, 2011; L52(54).

[8] http://agenda.ge/en/news/2014/1551

[9] Geostat, official census of citizens of Georgia 2014

[10] UN DESA, 2015. including the data from Abkhazia and Tskhinvali region occupied territories. The data of the accounting years: 2000, 2005, 2010 and 2015, July $1^{\text {st. }}$ The types of the data: population born abroad (B), (B), refugees of UNHCR (R).

[11] Eurostat (https://ec.europa.eu/home-affairs/what-we-do/policies/bordersand-visas/visa-policy en 31.10.2019) 